it was made into a skeleton, and then Dr. Günther discovered that the skull at the College of Surgeons and the skull of the Lizard I had named Hatteria were most probably the same. It should now be called Sphenodon punctatum.

I was much struck with the peculiar formation of the skull, and that induced me to describe it; but I did not then attach the great importance to its structure that Dr. Günther has since done: I only regarded it as one of the variations of structure that are found in most families. Indeed, when I consider the almost universal disinclination that zoologists have shown, almost up to this time, to admit the distinction of the two great families of Lizards, Agamidæ and Iguanidæ, which are so well characterized by the teeth and geographical distribution, it would have required more than usual hardihood in 1831, when the genus was described, to venture to form for it even a family; while an order may now be suggested for the single genus, with every probability of its being adopted-a decided proof of the progress of the science in a few years.

\title{
Deep-sea Dredging.
}

To the Editors of the Annals and Magazine of Natural History.

Gentlemen,-Y You will confer a favour on me, and, at the same time, enable me to acknowledge an act of courtesy on the part of my friend Dr. E. Perceval Wright, by inserting in the 'Annals' the following correspondence, which has already appeared in the pages of 'Scientific Opinion.'

Kensington, Jan. 13, 1869.

I remain, Gentlemen, Yours very faithfully,

" To the Editors of Scientific Opinion.

“Deep-Sea Dredging and Dr. Wallich.

"SIR,-I neglected to read 'Scientific Opinion' for the 16th inst. until a day or two ago, when I perceived you had done me the honour of transferring to your paper my few brief notes on 'Deep-Sea Dredging,' published in the 'Annals and Magazine of Natural History for this month. I was, however, at the same time very much grieved to find, from a footnote which you have appended to the first portion of my notes, that I have appeared to you to make little of Dr. Wallich's researches.

"I assure you and my friend Dr. Wallich that nothing was further from my thoughts. Few are, I think, better acquainted with the writings of Dr. Wallich than I am, and I yield to none in my appreciation of their value. Science has lost a great deal by the delay in the publication of the second part of his 'North-Atlantic Sea-Bed;' and no matter what may be the discoveries of future investigators, it is to the Rosses and Wallichs that we are indebted for our truest and earliest information on the subject. 
"My notes had only to do with the use of the dredge, and what I meant to convey was 'Dr. Wallich records the presence of life at great depths ; but the animals thus recorded belong to the Protozoa, with the exception of the Ophiocoma. Now, this was taken, not by the dredge, but by the accident of its clinging to the sounding-line ; for the purpose of demonstrating the occurrence of Echinoderm life at such depths, it was as valuable a fact as if a hundred starfishes had been taken by a dredge. But, after all, it is not with a sounding-line, but with a dredge, that we must look for these forms of life; and as by the use of this machine I have found some additional forms, I hasten to record them,' \&c. Again expressing my regret that I so wrote the sentence you extract that it should appear even for a moment to make little of the persevering labours of my accomplished friend, and trusting you will publish at least the substance of this letter in your early number of 'Scientific Opinion,'

"I remain, \&c.

"ED. Perceval Wright, M.D."

" Museum, Trinity College, Dublin.

Dec. 26."

\section{"The Dredge and the Sounding-Machine at Great Depths.}

"SiR,-The frank and manly explanation offered by my friend Dr. E. Perceval Wright, in his letter published in 'Scientific Opinion' of the 30th ult., regarding the sense in which he used the term 'accidental,' when referring to the capture of the Ophiocoma from a depth of 1260 fathoms in the North Atlantic, deserves my warmest acknow ledgments; and I can only say that the manner in which he has withdrawn the sting from his words, the moment it was brought to his notice, proves him to be made of the right metal.

"I have accordingly to thank him for his letter, and also to express my obligation to you for showing, in the brief note which you appended to the transcript of Dr. Wright's paper on 'Deep-Sea Dredging,' that I was by no means solitary in the interpretation I put upon the second paragraph of his communication. In order, however, to remove any misconception that may exist as to the circumstances under which I failed to use the dredge in preference to the sounding-machine, and also to prove that the discovery of animal life at the greatest depths in the ocean was fully believed in by me even before the capture of the Ophiocomce set the question at rest for ever, I beg the attention of your readers to the subjoined extract of a letter addressed by me to Sir Leopold M'Clintock, when our expedition reached its extreme outward destination, at Sydney, in Nova Scotia, premising that I cannot doubt Sir Leopold would have cheerfully afforded me the opportunities I so earnestly solicited, had the instructions received from the Admiralty and the exigencies of an exceptionally tempestuous season permitted him to do so. $\mathrm{My}$ letter was dated Sept. 7th, 1860. In it, after drawing attention to the very meagre results attained during the outward voyage, and the comparatively small number of instances in which apparatus for Ann. \& Mag. N. Hist. Ser. 4. Vol. iii. 
bringing up specimens of bottom had been employed, I wrote as follows :-

" "In submitting these observations to your notice, I would at once disclaim any desire on my part to impede the ordinary duties of the expedition by an unreasonable regard for the objects I have in view. I would only request that during the remaining portion of the voyage, the circumstances may, if possible, be taken into consideration, both as regards the strictly deep-sea soundings and any opportunities for dredging in deep water that may present themselves. Under a conviction that you will give me credit for addressing you with no other desire than that proceeding from extreme anxiety to perform the task entrusted to me satisfactorily, I remain, \&c. \&c.'

"It will, I hope, thus become manifest that the comparatively limited number of animals belonging to the higher types which I was enabled to procure was the result of circumstances over which, unfortunately, I could exercise no control. Let me observe, however, that Dr. Wright labours under a serious misapprehension when he states that the Ophiocoma were the only creatures of a highly organized type which the 'Bulldog' soundings brought to light from abyssal depths.

"To the perfect facility with which the dredge may be used, even at the greatest depths, the operations conducted on board the 'Great Eastern' steamship, several years ago, whilst employed in recovering the lost telegraphic cables, bear ample testimony. It is to be hoped, therefore, that the exploration of the deep-sea bed, in the systematic manner which was proposed by me, in 1863, to the President and Council of the Royal Geographical Society, and received from that body most cordial approbation, may now obtain from Government the liberal encouragement which it deserves.

"Lastly, will you permit me to point out, with reference to an erroneous idea which has got abroad and been brought to my notice by several friends, that, so far from having ignored the observations of Sir John Ross, in Baffin's Bay, in 1818, and of Sir James Ross, in the Antarctic Seas, in 1848, I was the first person to exhume them from the ill-merited oblivion into which they had been allowed to fall, and to accord to these eminent navigators, in my 'NorthAtlantic Sea-Bed,' published in 1860, the credit to which they were undoubtedly entitled?

"Kensington, Jan. 3."

"I remain, \&c.

"G. C. WaLLich."

Note on the Genus Helleria.

By the Rev. A. M. Norman, M.A.

To the Editors of the Annals and Magazine of Natural History.

Gentlemen,-I should be obliged if you would allow me to correct an error in the characters of the genus Helleria as given by me (Ann. Nat. Hist. ser. 4. vol. ii. p. 418, the Number for December). Instead of "Superior antennæ slender, much shorter than inferior, with secondary appendage," it should be "Superior antennæ \&c. without secondary appendage," as will be seen by reference to the 


\section{$2 \mathrm{BHL}$ Biodiversity Heritage Library}

1869. "Deep-sea dredging." The Annals and magazine of natural history; zoology, botany, and geology 3, 168-170.

https://doi.org/10.1080/00222936908695905.

View This Item Online: https://www.biodiversitylibrary.org/item/61863

DOI: https://doi.org/10.1080/00222936908695905

Permalink: https://www.biodiversitylibrary.org/partpdf/58475

\section{Holding Institution}

University of Toronto - Gerstein Science Information Centre

\section{Sponsored by}

University of Toronto

\section{Copyright \& Reuse}

Copyright Status: NOT_IN_COPYRIGHT

This document was created from content at the Biodiversity Heritage Library, the world's largest open access digital library for biodiversity literature and archives. Visit BHL at https://www.biodiversitylibrary.org. 